\title{
AMENITY MIGRATION IN POSTSOCIALIST METROPOLIS: THE CASE OF RIIGA AGGLOMERATION
}

\author{
Māris Bērziṇš and Zaiga Krišjāne \\ Faculty of Geography and Earth Sciences, University of Latvia, Raina bulv. 19, Rīga, LV-1586, LATVIA \\ E-mail: zaiga.krisjane@lu.Iv
}

Communicated by Pārsla Eglīte

\begin{abstract}
Over the last ten years, the metropolitan area of Riga has seen a population increase, while the number of people actually living in the city of Riga has declined. The aim of this paper is to analyse the process of deconcentration in the Riga agglomeration, linking these to motivation for migration and changes in the territorial distribution of places of residents. The study analyses factors that lead people to choose a specific place of residence. A comparison of motivation for migration in Riga and in the zones of its agglomeration shows that there are significant differences in terms of a job as a motivation factor. More important in selecting a new home are the purchase or construction of property, the desire for an attractive environment, and the ability to move into a better home. Efforts to improve quality of life are more distinct in the internal zone of the agglomeration, which means that environmental amenities play a more important role there than in the external zone.
\end{abstract}

Key words: environmental amenities, deconcentration, migration, quality of life, agglomeration.

\section{INTRODUCTION}

Mobility studies in the past have offered an extensive description of migration models, flows of migration, factors which influence these, motivations for migration, as well as the intention of people to change their place of residence. Researchers have not developed a unified approach vis-àvis the dominating factors in terms of characterising internal migration. The traditional belief in terms of factors leading people to migrate within their own country is that these are economic factors, urban factors (the urban lifestyle) and demographic factors (Lessinger, 1991; Richardson, 1973). The desire of individuals and households to change their place of residence is reviewed from two perspectives in the scientific literature-as an economic model related to human capital, and as an alternative hedonic model. The human capital model is used to analyse regional differences in terms of the labour market, along with the uneven economic development of various territories. The hedonic model accents the influence of non-traded goods on reasons as to why households move from one place to another (Clark and Cosgrove, 1991). Since the mid-20th century, the literature has extensively reviewed reasons for a deconcentration of populations, with residents abandoning densely populated regions and cities in favour of life in the countryside. These reasons for migration are often of a social nature, and in this they are in opposition to the once-dominant tendency of migration to flow toward urban areas. This has to do both with changes in the behaviour or individuals and with new opportunities for establishing a home (Frey, 1988).
Deconcentration processes and prevailing motivations for migration. One process that can be used to characterise the deconcentration of populations as the result of migration is known as counterurbanisation. This term at first was used to describe all types of population deconcentration outside the boundaries of cities (Champion, 1989). Later the term was used to describe the move of local residents to lower levels of the urban hierarchy (small towns, villages and hamlets) or to more distant rural territories (Berry, 1976; Ford, 1999). In analysing the process of counterurbanisation in more than 20 countries, researchers concluded that the main reasons for deconcentration have had to do with a reordering of economic processes (Vinning and Kontuly, 1978). In trying to differentiate between counterurbanisation and suburbanisation, it has been suggested that use be made of analysis of the behaviour and motivation of migrants-the so-called individual level/behavioural approach (Fisher, 2003). Thus, counterurbanisation represents the desire of local residents to enjoy the advantages of a rural way of life-landscapes, less pollution, peace and quiet. Other researchers also address such issues as the attractiveness of the surrounding environment, improved communications, specific demographic circumstances, the development of the service sector, and the attractiveness and amenities of the countryside. There are also specific push factors which encourage people to leave cities (Dahms and McComb, 1999).

Research has also stressed the fact that the development of the rural environment and, particularly, its infrastructure will in and of itself create possibilities for a shift in migra- 
tion directions in favour of those territories (Stockdale et al., 2000). As noted, migration research in the past emphasised the role of economic motivation in terms of regional differences in income levels, e.g., differences between urban and rural areas. Most of these theories insist that population migration has to do with rational economic decisions, evaluation of material advantages, and the selection of a place of residence that will ensure material well-being (Jobes, 2000). This approach, however, neglects other important socio-demographic factors that have an effect on migration-age, family status, gender and ethnicity, for instance. Demographic characterisations of the individual are important factors in mobility.

It is usually believed that younger and more highly educated groups of residents are more likely to be mobile than others. Decisions about migration, however, are made at the individual level. Each potential migrant will face different costs in terms of moving and looking for work, as well as of housing. The decision to move can be related not just to conditions in the labour market, but also to the attractiveness of territories, the quality of life, related costs, including housing costs, services at a higher level of standards, and the attractiveness of the surrounding environment (Portnov, 2001).

Migration is also linked to important phases in the human life cycle-obtaining an education, finding work, establishing a family (Krupka, 2004; Lundholm, 2006). Men migrate slightly more than women do, but not to a statistically significant degree. In Estonia, researchers did not find any increased migration among people of pension age, even though in Western countries such migration tends to be very intensive (Kulu and Billari, 2004).

A review of all of the aforementioned studies which have focused on deconcentration of populations and the causes for such migration leads one to agree with the claim that these can all be correlated into the single concept of "quality of life" (Findlay and Rogerson, 1993). Migration among rural people, moreover, is more affected by economic indicators, while for urban residents, the attractiveness of the place of residence and the available amenities are also of importance (Ferguson et al., 2007). A nice living environment, a well-developed infrastructure and an attractive image for the relevant city will mostly attract young migrants and their families (Niedomysl, 2006).

When migration is linked to quality of life, one of the most important assessments, according to research, is satisfaction with the surrounding environment and the quality thereof. In Latvia, research has focused more on satisfaction with living conditions and the way in which these affect human health, as well as on the availability and accessibility of services (Eglīte, 1992; Markausa, 1997; Krisjane, 2000; Vaskis, 2001). There has been virtually no assessment of the quality of life in relation to a suburban environment or of motivations for migration in relation to the attractiveness of the environment. An urban environment study that was conducted in 2000 showed that people in various parts of
Riga held the attractiveness of the environment and the amenities of the territory to be very important. Factor analysis of the urban environment showed this-the definitive factor in the environment was the quality of that environment, and the dominant variables were the attractiveness of the environment, the amenities that were available in the territory, and the quality of the environment (Bauls et al., 2003). Assuming that many of the people of Rìga have moved to the city's suburbs, these factors could be of importance in selecting a place of residence. In describing motivation for migration, therefore, it is important to evaluate the extent to which these are affected by a desire for a better quality of life, this referring not just to social and economic, but also to environmental aspects, which can be characterised on the basis of amenities.

Specific aspects of amenity migration. The concept of amenity migration has been described differently in various areas, but the definition proposed by Moss will be used for the purposes of this paper: "Environmental Amenities are the valued natural physical attributes of a place, including terrestrial and aquatic landscapes, distinguishing topographical features, climate, air, water and biodiversity quality and quantity" (Moss, 2006, p. 8). Laurence A.G. Moss was among the first to identify factors related to the development of the amenity migration construction. He first used the term "amenity migration" in 1985/86 (Glorioso, 2000). The author identifies not just environmental, but also cultural amenities (Moss, 2006). In the first amenity migration studies, climate was considered to be the most significant regional amenity, but other amenities were also acknowledged-mountains, beaches, hunting and fishing opportunities, availability of other sports, and the beautiful environment of small towns (Ullman, 1954).

It was specifically those authors who wrote about amenity migration who supplemented economic forces which affect migration with site-specific amenities (Rosen, 1974). It does have to be noted, however, that initially the authors insisted that amenity migration is possible only if the labour and housing markets are in balance, or if there are only minor differences in salaries and housing prices from the regional perspective. Roback (1982) included amenity migration into the quality of life index. The link among amenities, quality of life and migration has also been emphasised by Rudzitis, who studied the rural quality of life and wilderness of the United States (Rudzitis, 1996; 1999). In general, amenity migrants are people who choose to move to rural communities or the surrounding areas for perceived or actual environmental and/or social benefits (Glorioso and Moss, 2007).

Most theorists define "amenity" as a set of pleasant living conditions, the concept being linked to the development of a leisure (hedonic) society. Most definitions of amenity migration are limited to permanent residents (Chipeniuk, 2004), but some also cover seasonal and intermittent residents (Glorioso, 2000). Amenity migrants intend to settle in a new community either permanently or intermittently, to retire there, or to earn a living there (Glorioso and Moss, 


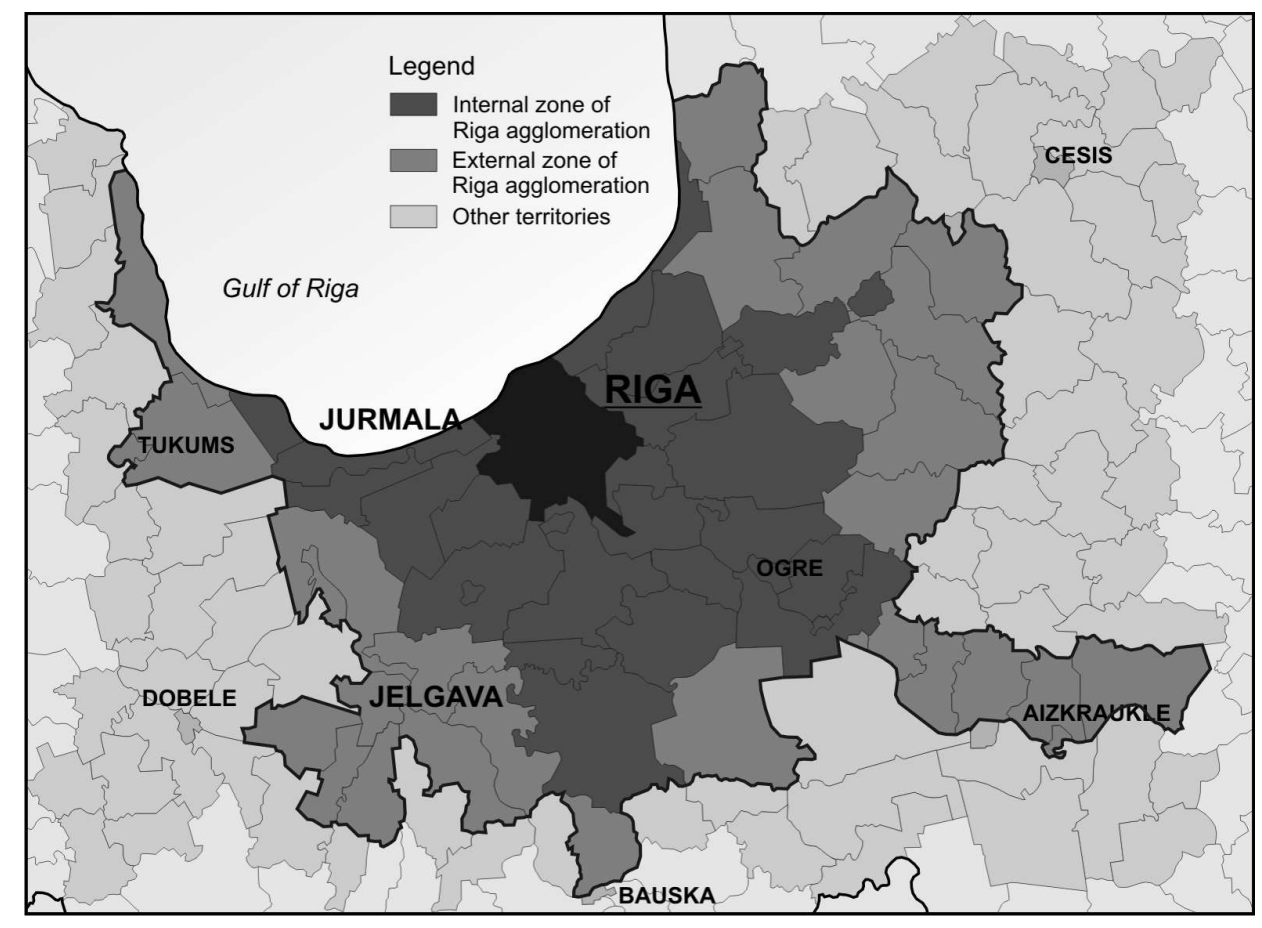

Fig. 1. Spatial structure of the Rìga agglomeration ${ }^{1}$.
2007). Graves and Linnemann (1979) has shown that amenities can influence the selection of a place of residents for people, while at the same time arguing that amenity migration is not a mass phenomenon when compared to traditional career-oriented migration (Greenwood and Hunt, 1989). In describing amenity migrants, it is emphasised that they often come from large cities or their environs. Such migrants tend to have a higher level of education and income than the local average. Studies focused on migrants stress that they are focused on a permanent life in the new place of residence, although that does not exclude the purchase of a second home (Glorioso and Moss, 2007).

Over the last ten years, the metropolitan area of Riga has seen a population increase, while the number of people actually living in the city of Rīga has declined. There has been no study in Latvia of how the process of deconcentration in the agglomeration-one that has been typical of other developed countries in the past-can be linked to the placement of various groups of residents in the area. From this perspective of migration research, it is of importance to evaluate the motivation for migration in the territory and to look at how the processes of migration characterise the distribution of local residents. In other words, what are the factors leading people to choose a specific place of residence?

The aim of this paper is to analyse the process of deconcentration in the Riga agglomeration, linking these to motivations for migration and changes in the territorial distribution of places of residents as a result of migration.

\section{DATA AND METHODS}

Latvia and the Rìga agglomeration as a case study. Latvia has a monocentric urban system, with a distinct concen- tration of residents around the capital city of Rìga. This creates a vast agglomeration for the city. The territorial structure of this area is made up of capital Rìga as the central city and then with the internal and external zone of the agglomeration (see Fig. 1). The two zones differ from one another in terms of their location in relation to Riga, the nature of interaction between the zone and the capital city, the intensity of daily commuting, and the density of residents and populated areas.

Rìga has a very high level of migration, although the intensity of migration is lower than in other regions. The greatest changes have occurred in the Riga metropolitan area (Jūrmala, plus the Rīga, Ogre, Limbaži and Tukums districts), and migration has led to population increases, both in cities and in the countryside. That is because there has been extensive housing construction. Changes in population numbers and the consequences thereof are particularly typical of territories which are alongside the city of Riga. These are undergoing rapid processes of suburbanisation.

The level of migration intensity in the Rīga metropolitan area is high, and there are distinct migration links to Rīga. Many former residents of the capital city still work there. This has increased the flow of daily commuting, because many people from the surrounding area go to work in Riga because they cannot find a job at home or are unhappy with salaries that are being offered near their place of residence. The offer and availability of jobs in Riga facilitates this commuting flow. Also, of importance are the dense network of roads and the availability of suburban public transportation services. The distinct concentration of a labour force with a comparatively higher level of education makes it eas-

${ }^{1}$ Department of Human Geography, University of Latvia. A study of population mobility in the Riga agglomeration. 2004. Unpublished materials (in Latvian). 
ier for businesses to attract any type of workers among residents of the city, or among people who engage in daily or weekly daily commuting. It is thanks to these migrants that other local governments receive individual income tax contributions proportional to what their residents have earned in Riga. Many of those who live outside of Rìga but work in the capital city spend an hour or even two hours en route in each direction. This has led many commuters to look for places of residence closer to where they work-in Riga or one of its suburbs.

This paper is based on the results of a study called "The Geographic Mobility of the Labour Force", which was conducted by the Latvian Ministry of Welfare under the auspices of the European Union Structural Fund programme "Labour Force Research" (Study No. VPD1/ESF/NVA/04/ NP/3.1.5.1/0003). The 2006 study involved a survey of 8,005 respondents in Latvia who were aged 15 to 65 . This cohort offered representative data not just about Latvia as such, but about each of its regions, as well (Krišjāne et al., 2007). Data from the study make it possible to develop an in-depth description of domestic migrants, as well as to analyse the motivation for migration at a greater depth. Data from the Central Statistical Bureau (CSP) on migration and daily commuting have also been accessed.

The migration survey also registered those residents who have changed places of residence within their own local government territory. Statistics about migrants, however, list only those residents who have moved to a different local government territory. In order to compare these data with information from the CSP, let us posit that migrants are people who have moved to a different local government territory.

In reviewing domestic migration over the last ten years, we can divide migrants into groups in terms of how long they have lived in a specific place of residence. The intensity of domestic migration over the last year has been nearly two times higher than in previous periods. This is confirmed by CSP data, because when declaration of places of residence was introduced, the number of domestic migrants increased rapidly.

Researchers found that 1,180 respondents had changed their place of residence over the previous ten years in Latvia, and $20.2 \%$ of them had done so in 2006. The proportion of male migrants was slightly higher than that of female migrants (53.2\%). In migration to Riga, the proportion of men was as high as $63 \%$.

Respondents have the following distribution by zones in the Rìga agglomeration: 2,688 in Rīga, 863 in the internal zone and 625 in the external zone.

Survey respondents were arranged into age groups. Respondents were asked questions about changes in their place of residence over the previous ten years, about motivation for the move, about their everyday mobility, and their future intentions with regard to migration.

\section{RESULTS}

Motivation for migration in Latvia's regions. Before migration processes and flows can be determined, it is important to learn about the motivation for migration. That makes it possible to explain differences in mobility in Latvia's various regions.

Among all reasons for moving to a new place of residence, family circumstances were mentioned most often (48\%), followed by work $(30 \%)$ and studies $(15 \%)$. In $8.1 \%$ of cases, the move occurred because a new home had been purchased or constructed (Krišjāne et al., 2007). Researchers also looked at motivation on the basis of how long the respondent had lived in his or her new place of residence. Those who had moved one year previously most often did so for family reasons $(43 \%)$ or because of studies (20\%). Those who had lived in the new place of residence for five to ten years reported motivation of studies in only $7 \%$ of cases, while family circumstances were cited fully $64 \%$ of the time. This suggests that comparatively intensive migration for purposes of studies has gradually decreased. This is also seen in the fact that this is one of the most important motivations for younger respondents - the dominant one among respondents in the 15-19 age group.

Reasons for moving to a new place of residence differ from one age group to the another. Family circumstances are more commonly cited in older age groups-34\% in 15-19 group, but fully $66 \%$ in the $60-65$ age group. There is a similar increase in proportions when it comes to buying or building a new home-from $1.6 \%$ in the youngest to $18.6 \%$ in the oldest age group. There were no significant differences among age groups when it came to moving for work purposes, although the proportion of that motivation increased along with higher levels of education. Among residents with an elementary education, $23 \%$ mentioned work as a reason for their move, while among those with a higher education, it was cited $40 \%$ of the time (Krišjāne un Bauls, 2007). This shows that people with a higher education are comparatively more mobile, and it is important for them to find work that is appropriate for their qualification. In greater distances, economic motivations are often dominant, and a change in the place of residence is often linked to changes in the local labour market.

Many people who live in the Rìga metropolitan area have high levels of education and qualification, and Rìga is the place where they can find appropriate jobs (Krišjāne un Bauls, 2005; (Krišjāne et al., 2007)). Respondents in the metropolitan area more often cited family circumstances, the purchase of new property and the attractiveness of the place of residence than residents of Riga did, and people in the former group were also more likely to appreciate the convenient location of the new place of residence and the availability of transportation services. Among those who chose to move to Rìga, location and amenities in the area were less important. $4.9 \%$ of respondents said that their new home was better than the previous one, while in the Riga 
MOTIVATION FOR MIGRATION IN LATVIA OVER THE LAST TEN YEARS (\% of responses) ${ }^{1}$

\begin{tabular}{|c|c|c|c|}
\hline Reason for moving & In Latvia & To Rīga & $\begin{array}{c}\text { To Rīga metro- } \\
\text { politan area }\end{array}$ \\
\hline Family reasons & 48.0 & 38.4 & 55.5 \\
\hline Work & 30.9 & 44.2 & 20.2 \\
\hline Studies & 15.2 & 29.6 & 3.5 \\
\hline Cheaper life & 4.6 & 0.9 & 6.9 \\
\hline $\begin{array}{l}\text { Recovery or inheritance of } \\
\text { property }\end{array}$ & 1.8 & 0 & 3.4 \\
\hline $\begin{array}{l}\text { Purchase or construction } \\
\text { of property }\end{array}$ & 8.4 & 3.9 & 18.2 \\
\hline $\begin{array}{l}\text { Enjoy new neighbourhood, } \\
\text { environment }\end{array}$ & 3.2 & 0.9 & 7.1 \\
\hline More convenient transport & 2.9 & 0.9 & 5.3 \\
\hline Good location & 4.3 & 2.1 & 5.7 \\
\hline $\begin{array}{l}\text { More opportunity for } \\
\text { leisure }\end{array}$ & 1.3 & 0 & 2.7 \\
\hline $\begin{array}{l}\text { More sports and cultural } \\
\text { events }\end{array}$ & 0.5 & 0.9 & 0.4 \\
\hline $\begin{array}{l}\text { Access to kindergartens, } \\
\text { schools }\end{array}$ & 1.2 & 0.9 & 2.3 \\
\hline New home is better & 6.6 & 4.2 & 9.3 \\
\hline
\end{tabular}

metropolitan area, a better home was chosen two times more (see Table 1) (Krišjāne un Bauls, 2007).

Motivations for migration in the Rìga agglomeration. If we compare motivation for migration in the various zones of the Rìga agglomeration, then we see that family reasons are dominant in all zones outside of the capital city. In the internal zone of the agglomeration, the next most important motivation has been the purchase or construction of real estate. This is confirmed by the fact that population numbers have been increasing in those local government territories which have borders with Riga. In this zone, respondents cite the attractiveness of the environment as a factor in their selection of a place of residence. People want to live in a nice environment. Respondents with a higher level of income mentioned this attractiveness more often than others.

Table 2 shows that some respondents felt that moving out of Rìga would allow them to enjoy a cheaper life. There are several processes in place here-purchase of property is typical of the middle class. There are people who want a larger home but cannot afford to buy such a home in Rìga. Still others find that the cost of living in Riga is too high, and they move to the countryside or to small towns. Older people are among such migrants. In both internal and the external zone of the agglomeration more people paid attention to the location of their home and to the availability of transportation services than did people in Rìga. As noted, work motivation were dominant in Rīga, and it can be assumed that the comparatively high proportion of this moti-

\footnotetext{
${ }^{1}$ Krišjāne, Z., Eglīte, P., Bauls A, Lulle, A., Bērziņš, M., Brants, M., Cunska, Z., Gnedovska, I., Ivbulis, B., Kanējeva, G., Kristaps, G., Krūzmētra, Ž., Kūle, L., Markausa, I.M., Niklass, M., Pavlina, I., Titova, N., Vanaga, S., Vilciňš, A., Zarina, I.B. The Geographic Mobility of the Labour Force. Rịga: University of Latvia, 2007. Unpublished materials (in Latvian).
}

MOTIVATION FOR MIGRATION IN THE RĪGA AGGLOMERATION (RAGL) ZONES OVER THE LAST TEN YEARS (\% of responses) $)^{2}$

\begin{tabular}{l|c|c|c}
\hline \multicolumn{1}{c|}{ Reason for moving to } & Rīga & $\begin{array}{c}\text { Internal zone } \\
\text { of RAGL }\end{array}$ & $\begin{array}{c}\text { External zone } \\
\text { of RAGL }\end{array}$ \\
\hline Family reasons & 38.4 & 53.7 & 46.7 \\
Work & 44.2 & 20.2 & 17.7 \\
Studies & 29.6 & 2.7 & 20.2 \\
Cheaper life & 0.9 & 8.3 & 7.5 \\
Purchase or construction of & 3.9 & 21.8 & 11.0 \\
property & & & \\
Enjoy new neighbourhood, & 0.9 & 9.6 & 1.1 \\
environment & & & \\
More convenient transport & 0.9 & 6.5 & 4.7 \\
Good location & 2.1 & 6.8 & 5.2 \\
More opportunityfor leisure & 0 & 3.7 & 2.7 \\
Access to kindergartens, & 0.9 & 2.2 & 1.5 \\
schools & & & 6.2 \\
New home is better & 4.2 & 9.2 &
\end{tabular}

vation in other zones can be attributed to the availability of jobs in the capital city and in the internal zone of the agglomeration. Riga has a more diverse structure of economic sectors, and that means a greater demand for labour, particularly in those professions requiring the highest qualifications. That is why many young people who receive their education in Rīga find jobs in the capital city and do not return to their place of origin. For many migrants, however, the cost of living in the capital city is too high, and so they instead choose to live in its environs.

Migration to the capital city has most often been reported to be related to work motivations in other studies of interregional migration (Hazans, 2003). Presently there are comparatively few migrants who move to the outer zone of the agglomeration just because they want to live in a pleasant environment. The results of the survey shows that this was one of the least often cited motivation among those respondents who moved to the outer zone of the agglomeration.

\section{DISCUSSION}

There has been little focus in Latvia on the attractiveness of the environment and surroundings of people from the perspective of migration. Most studies have analysed the availability of the socioeconomic infrastructure, or the ability of people to find work or to obtain an education. Far less attention has been devoted to such aspects of the quality of life as an attractive landscape, or the advantages of the rural life. These are issues that have been studied in great detail in the West (Berry, 1976; Findlay and Rogerson, 1993).

The results of this study clearly show that motivation related to economic issues and quality of life is important in the internal zone of the Riga agglomeration, and that has very much to do with processes of suburbanisation. This indicates that there is still a significant concentration of the

\footnotetext{
${ }^{2}$ Ibid.
} 
population in the nucleus of the agglomeration and in the immediate environs of this main centre for employment in Latvia. The Latvian public is still in the distinct period of productionism, when economic resources are accumulated. In several studies in Western countries, the opposite trend has been seen: those people who live further away from metropolises choose to live there because of the high quality of life that is available there (Halliday and Coombest, 1995; Lewis, 2000). This is not the case in the Riga agglomeration, even as population numbers in the outer zone of that agglomeration have increased. It must be noted here, however, that there is a lack of objective indicators regarding evaluation of the amenity in target territories for migration can be evaluated. It would be interesting to compare territories that are more valuable in terms of quality of life from this perspective to those that are in the strongly urbanised internal zone of the Riga agglomeration.

When people move to the countryside in Latvia, it is not for reasons of amenity migration. Rather, this is a process of deconcentration in the population, and economic factors are of key importance here. Studies in Latvia have found that migration to the countryside has been of a temporary nature (in the mid-1990s, there was a distinct increase in migration from cities to rural areas, and distant rural areas had a positive net migration with Riga). Far more durable processes of deconcentration are occurring in the Riga agglomeration, with movement increasingly toward regions outside of the metropolis. Similar processes of suburbanisation are seen in the urban regions of other post-Socialist countries (Ott, 2001; Tammaru, 2005; Boren and Gentile, 2007; Ourednicek, 2007; Sykora and Novak, 2007).

In conclusion, migration is a manifestation of mobility in a country. This is something that is very closely linked to individual decisions about moving to a new place of residence, as well as to the ability of people to pursue those intentions. Analysis of motivations for migration in Latvia and of changes that have occurred in the territorial placement of places of residence conjured up the challenge of how one can link two different sets of factors affecting migration in the population-economic factors which have to do with employment and the material welfare of Latvia's residents, as well as aspects of quality of life which are not unambiguous, but which are closely linked to the living environment and to aspects of individual growth.

A comparison of motivations for migration in Rìga and in the zones of its agglomeration shows that there are significant differences in terms of a job as a motivation factor. More important in selecting a new home are the purchase or construction of property, the desire for an attractive environment, and the ability to move into a better home. Efforts to improve quality of life are more distinct in the internal zone of the agglomeration, which means that amenities play a more important role there than in the external zone.

People who have moved to the Rịga agglomeration maintain links to the capital city. This is seen in the intensity of daily commuting, because economic life and activities con- tinue to be concentrated in Riga and nowhere else. This allows us to conclude that processes of deconcentration at the current stage of urbanisation apply to the placement of people's homes, not of their economic activities.

\section{ACKNOWLEDGEMENTS}

This article was supported by ESF Project No. 2004/0001/ VPDI/ESF/PIAA/04/NP/3.2.3.1/0001/0001/0063

\section{REFERENCES}

Bauls, A., Krišjāne, Z. (2002). Latvian regional differences in the migration processes. Folia Geographica, 10, 55-63. (in Latvian)

Bauls, A., Krišjāne, Z., Mežciema, G. (2003). Evalution of the urban environment in the different parts of Rìga. Folia Geographica, 11, 79-95 (in Latvian).

Berry, B.J.L. (ed.) (1976). Urbanization and Counterurbanization. Beverly Hills: Sage Publications. 329 pp.

Boren, T., Gentile, M. (2007). Metropolitan processes in post-communist states: An introduction. Geografiska Annaler, 89 B (2), 95-110.

Central Statistical Bureau of Latvia (2006). Demography. Collection of statistical data. Riga. 140 pp.

Champion, A.G. (1989). Introduction: The counterurbanization experience. In Champion, A.G. (ed.). Counterurbanization: The Changing Pace and Nature of Population Deconcentration (pp. 1-18). London: Edward Arnold.

Chipeniuk, R. (2004). Planning for amenity migration in Canada. Mountain Research and Development, 24(4), 327-335.

Clark, E. D., Cosgrove, C. J. (1991). Amenities versus labor market opportunities: Choosing the optimal distance to move. J. Regional Sci., 31(3), 311-328.

Dahms, F. A., McComb, J. (1999). 'Counterurbanization', interaction and functional change in a rural amenity area-a Canadian example. J. Rural Studies, 15(2), 129-146.

Eglīte, P. (1992). Iedzīvotāju kvalitātes izpētes aizsākums [Beginnings of research on population quality]. Latvijas Zinātṇu Akadēmijas Vēstis, A daḷa, 6, 11-19 (in Latvian).

Ferguson, M., Ali, K., Olfert, M. R., D., Partridge, M. (2007). Voting with their feet: Jobs versus amenities. Growth and Changes, 38(1), 77-110.

Findlay, A., Rogerson, R. (1993). Migration, places and quality of life: Voting with their feet. In Champion, T. (ed). Population Matters, The Local Dimension (pp. 34-49). London: Paul Chapman Publishing.

Fisher, T. (2003). Differentiation of growth processes in the peri-urban region: An Australian case study. Urban Studies 40(3), 551-565.

Ford, T. (1999). Understanding population growth in the peri-urban region. Int. J. Popul. Geogr., 5, 297-311.

Frey, W.H. (1988). Migration and metropolitan decline in developed countries: A comparative study. Popul. Devel. Rev., 14(4), 595-628.

Glorioso, R.S. (2000). Amenity migration in the Sumava Bioregion, Czech Republic: Implications for ecological integrity. In Godde, P.M., Price, M.F., Zimmerman, F.M. (eds.). Tourism and Development in Mountain Regions (pp. 275-295). Oxford: CABI Publishing.

Glorioso, R.S., Moss, L.A.G. (2007). Amenity migration to mountain regions: Current knowledge and a strategic construct for sustainable management. Social Change, 37(3), 137-161.

Graves, P.E., Linneman, P.D. (1979). Household migration: Theoretical and empirical Results. J. Urban Econ., 6, 383-404.

Greenwood, J.M., Hunt, L.G. (1989). Jobs versus amenities in the analysis of metropolitan migration. J. Urban Econ., 25, 1-16. 
Halliday, J., Coombest, M. (1995). In search of counterurbanisation: Some evidence from Devon on the relationship between patterns of migration and motivation. J. Rural Studies, 11(4), 433-446.

Hazans, M. (2003). Determinants of inter-regional migration in the Baltic countries. In: 43rd Congress of European Regional Science Association, 27-30 August 2003, Jyväskylä, Finland, pp. 1-23.

Jobes, P. C. (2000). Moving nearer to heaven: The illusions and disillusions of migrants to scenic rural places. London: Praeger. $256 \mathrm{pp}$

Krisjane, Z. (2000). The Quality of Life, Environmental and Human Health Assessment in Latvia. In Owsinski, J., Johansson, M. (eds.). Global-Local Interplay in the Baltic Sea Region. Papers from the 5th International Nordic-Baltic Conference (pp. 422-432). Warsaw: The Interfaces Institute.

Krišjāne, Z., Eglīte, P., Bauls A, Lulle, A., Bērzinšs, M., Brants, M., Cunska, Z., Gņedovska, I., Ivbulis, B., Kan̄ējeva, G., Kristaps, G., Krūzmētra, Ž., Kūle, L., Markausa, I.M., Niklass, M., Pavlina, I., Titova, N., Vanaga, S., Vilciņš, A., Zariṇa, I.B. (2007) Darbaspēka ǵeogrāfiskā mobilitāte [The Geographic Mobility of the Labour Force]. Rīga: Latvijas Universitāte. 240 lpp. (in Latvian).

Krišjāne, Z., Bauls, A. (2005). Migrācijas reǵionālās iezīmes Latvijā [Regional features of migration in Latvia]. Demogrāfiskā situācija šodien un rīt. Stratēgeiskās analīzes komisija. Zinātniski pētnieciskie raksti 3(4), 130-149 (in Latvian).

Krišjāne, Z., Bauls, A. (2007). Migrācijas plūsmu reǵionālās iezīmes Latvijā [Regional features of migration flows in Latvia]. Paaudžu nomaiņa un migrācija Latvijā. Stratēg̣iskās analīzes komisija. Zinātniski pētnieciskie raksti, 4(15), 130-143 (in Latvian).

Krupka, J. D. (2004). Location-specific Human Capital, Migration and Amenities. Georgia State University: Urban and Regional Analysis Group. 45 pp.

Kulu, H., Billari, F. C. (2004) Multilevel analysis of internal migration in a transitional country: The case of Estonia. Regional Studies, 38(6), 679-696.

Lessinger, J. (1991). Penturbia. WA: Socio-Economic, Seattle. 340 pp.

Lewis, G. (2000). Changing places in a rural world: The population turnaround in perspective. Geography, 85(2), 157-165.

Lundholm, E. (2006). Are movers still the same? Characteristics of interegional migration in Sweden 1970-2001. Tijdschrift voor Economische en Sociale Geografie, 98(3), 336-348.

Markausa, I.-M. (1997). Dzīvesvietas pievilcības vērtējums un iespējamā migrācija Latvijas iedzīvotāju skatījumā [Attractivity of the actual place of residence and intentions to change it]. In Demogrāfiskā situācija Latvijas laukos un iekšèjā migrācija 90-to gadu pirmajā pusēe. Apcerējumi par Latvijas iedzīvotājiem. Nr. 1. Rīga: LZA Ekonomikas institūts, pp. 64-81 (in Latvian).

Moss, L.A.G. (2006). The amenity migrants: Ecological challenge to contemporary Shangri-La. In Moss, L.A.G. (ed.), Amenity Migrants: Seeking and Sustaining Mountains and Their Cultures (pp. 3-26). Wallingford, Oxfordshire: CABI Publishing.

Niedomysl, T. (2006). Migration and place attractiveness. Geografiska Regionstudier, 68, 46 pp.

Ott, T. (2001) From concentration to de-concentration-migration patterns in the post-socialist city. Cities, 18(6), 403-412.

Ourednicek, M. (2007). Differential suburban development in Prague urban region. Geografiska Annaler, 89 B(2), 111-126.

Portnov, B. (2001). Employment -Housing paradigm of internal migration: Evidence from Norway. Int. Migration, 39(2), 93-117.

Richardson, H. (1973) Regional Growth Theory. Macmillian Basingstoke, Lodon. 264 pp.

Roback, J. (1982). Wages, rents, and the quality of life. J. Polit. Econ., 90(6), $57-78$.

Rosen, S. (1974). Hedonic prices and implicit markets: Product differentiation in pure competition. J. Polit. Econ., 82(1), 34-55.

Rudzitis, G. (1996). Wilderness and the Changing West. New York: John Wiley \& Sons. 240 pp

Rudzitis, G. (1999). Amenities increasingly draw people to the rural west. Rural Devel. Persp., 14(2), 9-14.

Stockdale, A., Findlay, A., Short, D. (2000) The repopulation of rural Scotland and threat. J. Rural Studies, 16, 243-257.

Sykora, L., Novak, J. (2007). A city in motion: Time-space activity and mobility patterns of suburban inhabitants and the structuration of the spatial organization of Prague metropolitan area. Geografiska Annaler, 89 B(2), $147-167$.

Tammaru, T. (2005). Suburbanisation, employment change, and commuting in the Tallinn metropolitan area. Environ. Plan., 37 A, 1669-1687.

Ullman, E. L. (1954). Amenities as a factor in regional growth. Geogr. Rev., 44, 119-132.

Vaskis, E. (ed.) (2001). Living conditions in Latvia. Rīga: LR CSP, FAFO. 237 pp.

Vining, D. R., Kontuly, T. (1978). Population dispersal from major metropolitan regions: An international comparison. Int. Reg. Sci. Rev., 3(1), 49-73.

Received 14 May 2008

\section{PIEVILCĪGAS DZĪVES VIDES MEKLĒJUMU MIGRĀCIJA POSTSOCIĀLISMA METROPOLĒS: RĪGAS AGLOMERĀCIJAS PIEMĒRS}

Pēdējās desmitgades laikā Rīgas aglomerācijai raksturīgs iedzīvotāju skaita pieaugums, savukārt Rīgas pilsētā iedzīvotāju skaits samazinās. Līdz šim Latvijā nav pētīts, kā aglomerācijā notiekošie iedzīvotāju dekoncentrācijas procesi, kas raksturīgi citās attīstītajās valstīs, saistīti ar dažādu iedzīvotāju grupu izvietojumu aglomerācijā. Migrācijas procesu izpētē svarīgi ir izvērtēt iedzīvotāju migrācijas motīvus šajā teritorijā un novērtēt, kā migrācijas procesi raksturo iedzīvotāju izvietojumu, kādi faktori ietekmē dzīves vietas izvēles nosacījumus. Līdz šim nav vērtēta iedzīvotāju dzīves kvalitāte saistībā ar suburbāno vidi un migrācijas motīvi saistībā ar vides pievilcību. Izvērtējot migrācijas motīvus, svarīgi ir novērtēt, kā tos ietekmē vēlme uzlabot savu dzīves kvalitāti, ar to saprotot ne tikai tās sociālos, ekonomiskos, bet arī vides aspektus, kurus var raksturot, izmantojot jēdzienu „vides pievilcība” (amenity). Šī raksta mērkis ir analizēt iedzīvotāju dekoncentrācijas procesus Rīgas aglomerācijā, saistot tos ar migrācijas motīviem un izmainām dzīvesvietu teritoriālajā izvietojumā migrācijas rezultātā. Rakstā izmantoti Eiropas Savienības struktūrfondu Nacionālās programmas „Darba tirgus pētījumi” projekta Labklājības ministrijas pētījumi Nr. VPD1/ESF/NVA/04/NP/3.1.5.1./0003 pētījuma „Darbaspēka ǵeogrāfiskā mobilitāte” rezultāti. Šajā pētījumā 2006. gadā tika aptaujāti 8005 respondenti Latvijā vecumā no 15 līdz 65 gadiem. Analizējot iedzīvotāju migrācijas motīvus un notikušās pārmaiņas dzīvesvietu teritoriālajā izvietojumā, jāizvērtēe kā sasaistīt divus atškiirīgus iedzīvotāju migrāciju ietekmējošus faktoru kopumus-ekonomiskos, kas saistīi ar nodarbinātību un iedzīvotāju materiālās labklājības nodrošināšanu, un dzīves kvalitātes aspektus, kuri nav viennozīmīgi vērtējami, bet ir cieši saistīti ar dzīves vidi un indivīdu izaugsmes aspektiem. Salīdzinot pārcelšanās motīvus Rīgā un tās aglomerācijas zonās, vērojamas būtiskas atškirīīas darba vietai kā motivējošam faktoram. Jauna īpašuma iegāde vai celtniecība, pievilcīgas apkārtnes izvēle, kā arī kvalitatīva mājokḷa iegāde ien,em nozīmīgāku lomu, izvēloties jauno mājvietu. Centieni uzlabot savu dzīves kvalitāti ir izteiktāki aglomerācijas iekšējā zonā. Vides pievilcībai šajā zonā ir nozīmīgāka loma, salīdzinot ar ārējo zonu. 